\title{
Daya terima konsumen terhadap jelly drink belimbing wuluh (Averrhoa bilimbi L.)
}

\author{
Consumer's acceptance to belimbing wuluh (Averrhoa bilimbi L.) jelly drink
}

\author{
Romadhiyana Kisno Saputri ${ }^{1{ }^{*}}$, Akhmad Al-Bari ${ }^{1)}$, Ria Indah Kusuma Pitaloka ${ }^{1)}$ \\ ${ }^{1}$ Universitas Nahdlatul Ulama Sunan Giri Bojonegoro, Jawa Timur \\ *Email korespondensi : romadhiyana.ks@unugiri.ac.id
}

Informasi Artikel:

Dikirim: 15/10/2020; disetujui: 15/12/2020; diterbitkan: 30/03/2021

\begin{abstract}
Belimbing wuluh (Averrhoa bilimbi L.) is a well-known traditional medicinal plant that thrives in Indonesia. The amount of fruit production per year can reach 1500 pieces per plant but is easily damaged, its shelf life is short, the taste of sour fruit causes not many people to consume the fruit fresh, in addition, have a low selling price and economic value. Therefore to increase the storage capacity, selling price, and economic value it is necessary to process into functional foods such as jelly drinks. This study aims to determine consumer acceptance of Belimbing wuluh (Averrhoa bilimbi L.) jelly drink products. The method of this research was the design of random group. The first factor is the concentrate of carrageenans (1\%; $1,5 \% ; 2 \%)$ and the second factor is the concentrate of sugars $(13 \%, 15 \%)$. Observations on Belimbing wuluh (Averrhoa bilimbi L.) jelly drink (taste, color, aroma, suction power, and mouthfeel) by 25 untrained panelists. Organoleptic test data were analyzed by nonparametric statistical methods using the Friedman test. The results showed that the best treatments on consumer acceptance of jelly drink Belimbing wuluh (Averrhoa bilimbi L.) in an organoleptic manner was obtained from treatment with 1,5\% carrageenan and $15 \%$ sugar with a product value of 2,39 with a mean value of panelist favorability to taste on 6,23; the color on 7,76; aroma on 7,19; suction power on 8,5; mouthfeel on 7,54.
\end{abstract}

Keywords: consumer acceptance, jelly drink, Averrhoa bilimbi L.

\begin{abstract}
ABSTRAK
Belimbing wuluh (Averrhoa bilimbi L.) merupakan tanaman obat tradisional yang sudah sangat dikenal dan tumbuh dengan subur di Indonesia. Jumlah produksi buah pertahunnya bisa mencapai 1500 buah per tanaman namun sangat mudah rusak, daya simpannya singkat, harga jual buah belimbing wuluh di pasaran juga rendah. Jadi untuk meningkatkan daya simpan, daya jual dan nilai ekonomis perlu dilakukan pengolahan terhadap buah belimbing wuluh menjadi pangan fungsional seperti jelly drink. Penelitian ini bertujuan untuk mengetahui daya terima konsumen terhadap produk jelly drink belimbing wuluh. Percobaan ini menggunakan rancangan acak kelompok dengan 2 (dua) faktor. Faktor pertama adalah proporsi konsentrasi karagenan $(1 \% ; 1,5 \% ; 2 \%)$ dan faktor kedua adalah konsentrasi gula $(13 \%, 15 \%)$. Pengamatan dilakukan terhadap produk jelly drink belimbing wuluh (warna, rasa, aroma, daya hisap dan tekstur di mulut) dari 25 panelis yang tidak terlatih. Data uji organoleptik dianalisis dengan metode statistik non-parametrik menggunakan Uji Friedman. Hasil penelitian menunjukkan bahwa perlakuan terbaik secara organoleptik diperoleh dari perlakuan persentase karagenan 1,5\% dengan gula 15\%. dengan nilai produk sebesar 2,39 dengan karakteristik sebagai berikut: rerata nilai tingkat kesukaan panelis terhadap rasa 6,23; warna 7,76; aroma 7,19; daya hisap 8,5; tekstur di mulut 7,54.
\end{abstract}

Kata kunci : daya terima konsumen, jelly drink, Belimbing wuluh (Averrhoa bilimbi L.) 


\section{PENDAHULUAN}

Pangan fungsional merupakan makanan dan bahan pangan yang dapat memberikan manfaat tambahan di samping mempunyai fungsi gizi dasar pangan tersebut sesuai dengan posisinya dan bisa bermanfaat bagi kesehatan (Kusumayanti et al., 2016). Saat ini, kesadaran masyarakat tentang kesehatan dan gizi semakin meningkat, yang menyebabkan semakin meningkat pula pentingnya kesadaran untuk mengkonsumsi makanan atau minuman yang tidak hanya praktis penggunaannya tetapi juga memiliki manfaat bagi kesehatan seperti pangan fungsional (Nirwana et al., 2019). Pangan fungsional memiliki prospek yang bagus untuk dikembangkan di Indonesia dan juga mempunyai peluang dalam perdagangan ekspor, antara lain ke negara Jepang, Eropa dan Amerika. sehingga peluang pengembangan produk baru untuk dapat diterima konsumen secara luas terbuka lebar. Sifat fungsional dari pangan fungsional ditentukan oleh komponen bioaktif yang terkandung didalamnya (Susanto et al., 2019).

Belimbing wuluh (Averrhoa bilimbi L.) merupakan tanaman obat tradisional yang sudah sangat dikenal. Belimbing wuluh tumbuh dengan subur di Indonesia, Filipina, Sri Lanka, Myanmar, dan Malaysia yang dapat ditemui di tempat yang terkena sinar matahari langsung tetapi cukup lembab. Tanaman ini tidak termasuk ke dalam tanaman musiman. Jumlah produksi buah pertahunnya bisa mencapai 1500 buah per tanaman. Belimbing wuluh mempunyai kadar air tinggi $\pm 93 \%$ membuat buah ini mudah rusak dan daya simpannya singkat (4-5 hari). Rasa buah belimbing wuluh yang asam menyebabkan tidak banyak orang yang mengkonsumsi buah tersebut dalam keadaan segar. Harga jual buah belimbing wuluh di pasaran juga rendah, tidak banyak orang yang membutuhkan dan memanfaatkan buah tersebut untuk dikonsumsi. Jadi untuk meningkatkan daya simpan, daya jual dan nilai ekonomis perlu dilakukan pengolahan terhadap buah belimbing wuluh menjadi pangan fungsional (Aini et al., 2019). Buah belimbing wuluh memiliki kandungan beberapa jenis asam seperti asam asetat, asam sitrat dan asam format serta zat aktif lainnya seperti flavonoid, polifenol triterpenoid, saponin, tannin, flavonoid, dan alkaloid yang berpotensi sebagai aktivitas antihipertensi, antihiperlipidemia, antihiperglikemia antibakteri dan antioksidan. Hal ini mengakibatkan tanaman berpotensi dijadikan sebagai produk pangan fungsional (Andayani et al., 2014; Matondang et al., 2017; Wijanarti et al., 2016).

Pemanfaatan belimbing wuluh (Averrhoa bilimbi L.) berdasarkan penelitian beberapa tahun belakangan ini sudah menghasilkan produk yang lebih komersil. Hal ini mengakibatkan pemanfaatan tanaman ini sekarang sudah menjadi produk pangan dengan hasil olahan produk yang beraneka ragam seperti manisan kering, sirup, selai, jelly drink, permen keras, dan kurma (Insan et al., 2019). Jelly merupakan makanan ringan berbentuk gel yang dapat dibuat dari pektin, agar, karaginan, gelatin atau senyawa hidrokoloid lainnya dengan penambahan gula, asam dan atau tanpa bahan tambahan makanan lain yang diizinkan. Jelly drink merupakan minuman yang memiliki konsistensi gel yang lemah, sehingga memudahkan untuk disedot (Marin et al., 2016). Keunggulan jelly drink adalah memiliki kandungan serat yang tinggi sehingga baik untuk kesehatan pencernaan. Selain itu, jelly drink lebih diminati oleh masyarakat sebagai minuman penunda lapar yang sehat karena kaya vitamin $C$. Belimbing Wuluh (Averrhoa bilimbi L.) mengandung vitamin $C$ sebesar $25 \mathrm{mg} / 100 \mathrm{~g}$ buah segar, yang berguna sebagai penambah daya tahan tubuh dari perlindungan terhadap berbagai penyakit (Agustin dan Putri, 2013). Daya terima konsumen adalah tingkat kesukaan konsumen terhadap sesuatu (ZA et al., 2019) Daya terima konsumen yang dimaksud dalam penelitian ini adalah sikap konsumen terhadap rasa, warna, aroma, daya hisap (kemudahan untuk dihisap dengan sedotan) dan tekstur di mulut 
(Sugiarto, 2011). Penelitian ini bertujuan untuk mengetahui daya terima konsumen terhadap produk jelly drink belimbing wuluh.

\section{METODE}

\section{Bahan}

Bahan yang digunakan untuk pembuatan jelly drink meliputi belimbing wuluh yang diperoleh di pekarangan rumah dengan umur panen \pm 34 hari setelah bunga mekar, gula yang diperoleh dari pasar tradisional. Gelling agent yaitu karagenan yang diperoleh dari toko bahan kimia.

\section{Alat}

Alat yang digunakan untuk pembuatan jelly drink adalah pisau tahan karat, ember, juicer, panci stainless stell, thermometer, sendok, telenan, pangaduk, kompor, cup jelly drink.

\section{Rancangan penelitian}

Rancangan yang digunakan dalam penelitian ini menggunakan rancangan acak kelompok dengan 2 (dua) faktor. Faktor pertama adalah proporsi konsentrasi karagenan $(1 \% ; 1,5 \% ; 2 \%)$ dan faktor kedua adalah konsentrasi gula $(13 \%, 15 \%)$.

\section{Pengamatan}

Pengamatan dilakukan terhadap produk jelly drink belimbing wuluh (warna, rasa, aroma, daya hisap dan tekstur di mulut) dari 25 panelis yang tidak terlatih.

\section{Analisis data}

Data hasil uji organoleptik dianalisis dengan metode statistik non parametrik menggunakan Uji Friedman dengan $(\alpha=0,05)$, sedangkan perlakuan terbaik menggunakan indek efektifitas.

\section{HASIL DAN PEMBAHASAN}

\section{Rasa}

Hasil uji organoleptik pada rasa jelly drink belimbing wuluh menunjukkan bahwa rerata ranking kesukaan panelis terhadap rasa jelly drink belimbing wuluh berkisar antara 5,52- 7,48. Semakin tinggi rata-rata kesukaan panelis, maka semakin tinggi pula tingkat kesukaan panelis terhadap rasa jelly drink belimbing wuluh. Rerata nilai kesukaan panelis terhadap rasa jelly drink belimbing wuluh disajikan pada tabel 1 . Berdasarkan tabel 1, rerata nilai tingkat kesukaan panelis terhadap rasa jelly drink belimbing wuluh pada berbagai perlakuan yang dilakukan menunjukkan nilai terendah pada perlakuan karagenan $1,5 \%$ dan gula 13\%. Nilai tertinggi tingkat kesukaan panelis terhadap rasa jelly drink belimbing wuluh pada perlakuan karagenan $1 \%$ dan gula $15 \%$.

Hasil analisis Uji Friedman $(\alpha=0,05)$ menunjukkan bahwa terdapat perbedaan skor dalam setiap perlakuan, yang menunjukkan bahwa ada perbedaan rasa pada setiap perlakuan. Perlakuan terbaik tingkat kesukaan panelis terhadap rasa diperoleh dari karagenan 1\% dengan gula $15 \%$.

Rasa adalah sesuatu yang dirasakan didalam mulut yang merupakan perpaduan dari bau dan perasaan yang ditimbulkan dari suatu hidangan makanan dan minuman pada saat makan atau mencicipi makanan. Saat ini ada empat rasa dasar yang dapat dikenali oleh lidah yaitu, manis, asam, asin, dan pahit (ZA et al., 2019). Rasa yang dimaksud dalam penelitian ini adalah rasa manis keasaman khas belimbing wuluh pada jelly drink belimbing wuluh. Buah belimbing wuluh memiliki kandungan asam sitrat dan asam oksalat, sehingga buah belimbing wuluh segar memiliki rasa asam, dengan adanya penambahan gula, diharapkan dapat meminimalisir rasa asam pada olahan jellydrink belimbing wuluh.

Pada penelitian ini, dengan konsentrasi karagenan yang sama, semakin besar kandungan gula pada jelly drink belimbing wuluh, semakin besar pula rerata tingkat kesukaan panelis terhadap jelly drink belimbing wuluh. Hal ini sesuai dengan penelitian. Merta (2017) yang menunjukkan semakin banyak penggunaan kadar gula maka semakin terasa manis permen jeli belimbing wuluh. Panelis menyatakan bahwa rasa pada jelly drink belimbing wuluh masih terasa asam khas belimbing wuluh, 
namun masih dapat diterima karena selain rasa asam juga ada rasa manis yang dihasilkan. Panelis juga merasakan rasa asam segar khas belimbing wuluh yang tidak hilang saat pengolahan menjadi jelly drink belimbing wuluh.

Perlakuan terbaik tingkat kesukaan panelis terhadap rasa diperoleh dari karagenan $1 \%$ dengan gula $15 \%$. Semakin meningkat konsentrasi karagenan, maka semakin menurun tingkat kesukaan panelis terhadap rasa. Hasil ini sejalan dengan penelitian Gani et al. (2014) yang menunjukkan nilai kesukaan terhadap rasa jelly drink rosela-sirsak menurun seiring dengan meningkatnya konsentrasi karagenan yang ditambahkan. Untuk meningkatkan tingkat kesukaan terhadap rasa, jelly drink belimbing wuluh dapat menambahkan buah atau bahan lain yang memiliki rasa dasar manis, sehingga dapat menutupi rasa asam buah belimbing wuluh.

Tabel 1. Rerata tingkat kesukaan panelis terhadap rasa

\begin{tabular}{lc}
\hline \multicolumn{1}{c}{ Formula jelly drink } & Rerata tingkat kesukaan panelis \\
\hline Karagenan 1\% Gula 13\% & 6,64 \\
Karagenan 1\% Gula 15\% & 7,48 \\
Karagenan 1,5\% Gula 13\% & 5,52 \\
Karagenan 1,5\% Gula 15\% & 6,23 \\
Karagenan 2\% Gula 13\% & 5,56 \\
Karagenan 2\% Gula 15\% & 6,96 \\
\hline
\end{tabular}

Tabel 2. Rerata tingkat kesukaan panelis terhadap warna

\begin{tabular}{lc}
\hline \multicolumn{1}{c}{ Formula jelly drink } & Rerata tingkat kesukaan panelis \\
\hline Karagenan 1\% Gula 13\% & 7.44 \\
Karagenan 1\% Gula 15\% & 7.60 \\
Karagenan 1,5\% Gula 13\% & 7.64 \\
Karagenan 1,5\% Gula 15\% & 7.76 \\
Karagenan 2\% Gula 13\% & 7.80 \\
Karagenan 2\% Gula 15\% & 7.92 \\
\hline
\end{tabular}

\section{Warna}

Hasil uji organoleptik terhadap warna jelly drink belimbing wuluh menunjukkan bahwa rerata ranking kesukaan panelis terhadap warna jelly drink belimbing wuluh berkisar antara 7,44- 7,92 Semakin tinggi rata-rata kesukaan panelis, maka semakin tinggi pula tingkat kesukaan panelis terhadap warna jelly drink belimbing wuluh. Rerata nilai kesukaan panelis terhadap warna jelly drink belimbing wuluh disajikan pada tabel 2. Berdasarkan tabel 2, rerata nilai tingkat kesukaan panelis terhadap warna jelly drink belimbing wuluh pada berbagai perlakuan yang dilakukan menunjukkan yang semakin meningkat dengan semakin banyaknya konsentrasi karagenan dan gula yang ditambahkan. Nilai tinggi tingkat kesukaan panelis terhadap rasa jelly drink belimbing wuluh pada perlakuan karagenan 2\% dengan gula $15 \%$.

Hasil analisis Uji Friedman $(\alpha=0,05)$ menunjukkan bahwa terdapat perbedaan skor dalam setiap perlakuan, yang menunjukkan bahwa ada perbedaan warna pada setiap perlakuan. Perlakuan terbaik tingkat kesukaan panelis terhadap warna diperoleh dari $2 \%$ dengan gula $15 \%$.

Warna adalah komponen yang sangat penting dalam menentukan kualitas atau derajat penerimaan dari suatu bahan pangan. Suatu bahan pangan yang dinilai enak dan teksturnya baik tidak dimakan apabila memiliki warna yang kurang sedap dipandang atau sudah menyimpang dari warna yang seharusnya (Hartati dan Djauhari, 2017). Warna yang dimaksud dalam penelitian ini adalah kecerahan warna jelly drink belimbing wuluh. Jelly drink 
belimbing wuluh dibuat dari sari belimbing wuluh yang dihasilkan dari pencampuran belimbing wuluh dengan air dengan perbandingan 1:1. Sari belimbing wuluh selanjutnya ditambahkan dengan karagenan dan gula. Warna jelly drink belimbing wuluh adalah kuning muda dan agak sedikit keruh karena adanya campuran karagenan. Warna jelly drink sebagian besar hanya berasal dari warna alami sari belimbing wuluh yang dipengaruhi oleh tingkat kematangan buah, proses water blancing, perbandingan buah belimbing wuluh dan air serta bahan tambahan lainnya. Pada penelitian ini, warna jelly drink belimbing wuluh dipengaruhi oleh proses water blancing dan bahan tambahan lainnya karena tingkat kematangan dan perbandingan buah belimbing wuluh dan air yang digunakan pada penelitian ini adalah sama Proses water blancing yang bertujuan untuk mempertahankan warna agar tidak terjadi kecoklatan (Aini et al., 2018). Konsentrasi karagenan mempengaruhi kekentalan produk, hal ini dapat mempengaruhi tingkat kecerahan warna dari jelly drink (Selviana, 2016). Skor warna mempunyai peranan penting terhadap tingkat penerimaan produk secara visual, sehingga dalam pengembangan produk olahan perlu warna perlu diperhatikan dengan baik.

\section{Aroma}

Hasil uji organoleptik terhadap aroma jelly drink belimbing wuluh menunjukkan bahwa rerata ranking kesukaan panelis terhadap aroma jelly drink belimbing wuluh berkisar antara 5,96-7,19. Semakin tinggi rata-rata kesukaan panelis, maka semakin tinggi pula tingkat kesukaan panelis terhadap aroma jelly drink belimbing wuluh. Rerata nilai kesukaan panelis terhadap aroma jelly drink belimbing wuluh disajikan pada tabel 3. Berdasarkan tabel 3, rerata nilai tingkat kesukaan panelis terhadap aroma jelly drink belimbing wuluh pada berbagai perlakuan yang dilakukan menunjukkan jika dilihat dari persentase karigenan, terdapat hasil yang turun lalu naik lagi seiring dengan peningkatan proporsi karagenan. Nilai tinggi tingkat kesukaan panelis terhadap aroma jelly drink belimbing wuluh pada perlakuan karagenan $1,5 \%$ dengan gula $15 \%$. Hasil analisis

Uji Friedman $(\alpha=0,05)$ menunjukkan bahwa terdapat perbedaan skor dalam setiap perlakuan, yang menunjukkan bahwa ada perbedaan aroma pada setiap perlakuan. Perlakuan terbaik tingkat kesukaan panelis terhadap aroma diperoleh dari perlakuan karagenan $1,5 \%$ dengan gula $15 \%$.

Tabel 3. Rerata tingkat kesukaan panelis terhadap aroma

\begin{tabular}{lc}
\hline \multicolumn{1}{c}{ Formula jelly drink } & Rerata tingkat kesukaan panelis \\
\hline Karagenan 1\% Gula 13\% & 7,08 \\
Karagenan 1\% Gula 15\% & 5,96 \\
Karagenan $1,5 \%$ Gula $13 \%$ & 6,44 \\
Karagenan $1,5 \%$ Gula $15 \%$ & 7,19 \\
Karagenan $2 \%$ Gula $13 \%$ & 7,08 \\
Karagenan 2\% Gula 15\% & 6,52 \\
\hline
\end{tabular}

Aroma merupakan bau dari produk makanan, bau sendiri adalah suatu respon ketika senyawa volatil dari suatu makanan masuk ke rongga hidung dan dirasakan oleh sistem olfaktori. Senyawa volatil masuk ke dalam hidung ketika manusia bernafas atau menghirupnya, namun juga dapat masuk dari belakang tenggorokan selama seseorang makan. Senyawa aroma dapat ditemukan dalam makanan, anggur, rempah-rempah, parfum, minyak wangi, dan minyak esensial. Di samping itu senyawa aroma memainkan peran penting dalam produksi penyedap, yang digunakan di industri jasa makanan, untuk meningkatkan rasa dan umumnya meningkatkan daya tarik produk makanan tersebut (Tarwendah, 2017). Aroma yang dimaksud dalam penelitian ini adalah aroma 
khas jelly drink belimbing wuluh. Belimbing wuluh memiliki aroma green, dan terdeteksi memiliki 35 komponen volatile. Alpha-pinena (woody, fresh, herbal lift) dan etil (2E)-3-(4-hidroksi-3metoksifenil)-2-propenoat (floral, green, earthy) adalah senyawa yang diperkirakan berkontribusi dalam pembentukan aroma belimbing wuluh (Eren, 2015). Pada penelitian ini, aroma khas belimbing wuluh masih bisa tercium pada produk jelly drink belimbing wuluh, namun persentase karagenan dan gula tidak senantiasa sebanding dengan tingkat kesukaan panelis terhadap aroma jelly drink belimbing wuluh. Penelitian yang oleh Selviana (2016) menunjukkan semakin tinggi konsentrasi gula pasir dan karagenan menyebabkan penurunan nilai kesukaan dalam hal aroma, karena dengan peningkatan konsentrasi karagenan dan gula pasir menyebabkan peningkatan kekentalan dari minuman jelly yang mempengaruhi aroma. Pada penelitian ini aroma jelly drink belimbing wuluh dipengaruhi oleh persentase karagenan dan gula yang digunakan. Penilaian terhadap aroma dipengaruhi oleh faktor psikis dan fisiologis yang menimbulkan pendapat berlainan. Berdasarkan komentar yang diberikan panelis melalui kuisioner, aroma yang dominan adalah asam (Triswandari, 2006).

\section{Daya hisap}

Hasil uji organoleptik terhadap daya hisap (kemudahan untuk dihisap dengan sedotan) jelly drink belimbing wuluh menunjukkan bahwa rerata ranking kesukaan panelis terhadap daya hisap (kemudahan untuk dihisap dengan sedotan) jelly drink belimbing wuluh berkisar antara 1,52-8 5. Semakin tinggi rata-rata kesukaan panelis, maka semakin tinggi pula tingkat kesukaan panelis terhadap daya hisap (kemudahan untuk dihisap dengan sedotan) jelly drink belimbing wuluh. Rerata nilai kesukaan panelis terhadap daya hisap (kemudahan untuk dihisap dengan sedotan) jelly drink belimbing wuluh disajikan pada tabel 4. Berdasarkan tabel, rerata nilai tingkat kesukaan panelis terhadap daya hisap (kemudahan untuk dihisap dengan sedotan) jelly drink belimbing wuluh pada berbagai perlakuan yang dilakukan menunjukkan pada persentase gula 13\%, peningkatan persentase karagenan menyebabkan penurunan tingkat kesukaan panelis terhadap daya hisap (kemudahan untuk dihisap dengan sedotan). Nilai tinggi tingkat kesukaan panelis terhadap daya hisap (kemudahan untuk dihisap dengan sedotan) jelly drink belimbing wuluh pada perlakuan karagenan $1,5 \%$ dengan gula $15 \%$.

Hasil analisis Uji Friedman $(\alpha=0,05)$ menunjukkan bahwa terdapat perbedaan skor dalam setiap perlakuan, yang menunjukkan bahwa ada perbedaan daya hisap (kemudahan untuk dihisap dengan sedotan) pada setiap perlakuan. Perlakuan terbaik tingkat kesukaan panelis terhadap daya hisap (kemudahan untuk dihisap dengan sedotan) diperoleh dari perlakuan karagenan $1,5 \%$ dengan gula $15 \%$.

Jelly drink adalah produk minuman yang berbentuk gel dan memiliki karakteristik berupa cairan kental yang mudah disedot. Selain itu, jelly drink memiliki karakteristik gel yang berbeda dari produk jelly pada umumnya. Gel dari jelly drink lebih lunak (halus) dan teksturnya tidak kokoh, sehingga saat dikonsumsi lebih mudah disedot, tetapi saat dimulut masih dapat dirasakan tekstur gelnya (Ulfa et al., 2019). Daya hisap merupakan salah satu parameter penting untuk mengetahui karakteristik dan kekuatan gel pada jelly drink belimbing wuluh (Vania et al., 2017). Daya hisap yang dimaksud dalam penelitian ini adalah kemudahan untuk dihisap dengan sedotan jelly drink belimbing wuluh. Jelly drink belimbing wuluh disajikan dalam cup kecil puding berukuran $100 \mathrm{ml}$ dengan sedotan kecil berdiameter 0,6 cm. Kemudahan untuk dihisap dengan sedotan berkaitan dengan tekstur gel jelly drink belimbing wuluh. Pembentukan gel dipengaruhi oleh gula dan karagenan yang digunakan. Dari penelitian, peningkatan persentase gula menurunkan tingkat kesukaan panelis terhadap daya hisap (kemudahan dihisap dengan sedotan). Hal 
ini dikarenakan gula pasir selain berfungsi sebagai pemberi rasa juga berfungsi sebagai thickener yang menarik molekul-molekul air bebas gula pasir $10-15 \%$ dapat menghasilkan jelly drink dengan tekstur yang dapat diterima (Minarwan, 2019). Selain gula, persentase karagenan juga berhubungan dengan daya hisap jelly drink belimbing wuluh. Pada penelitian ini, perlakuan terbaik ada pada persentase karagenan $1,5 \%$ gula $15 \%$. Pada perlakuan ini tekstur gel lunak dan tidak encer sehingga mudah untuk dihisap dengan sedotan. Namun pada saat konsentrasi karagenan dinaikkan menjadi $2 \%$ dengan proporsi gula sama (15\%), gel menjadi susah dihisap. Hal ini disebabkan karena penambahan konsentrasi karagenan menyebabkan jumlah air yang terperangkap dalam gel banyak sehingga gel menjadi sedikit kaku dan susah dihisap dengan sedotan (Gani et al., 2014)

Tabel 4. Rerata tingkat kesukaan panelis terhadap daya hisap

\begin{tabular}{lc}
\hline \multicolumn{1}{c}{ Formula jelly drink } & Rerata tingkat kesukaan panelis \\
\hline Karagenan 1\% Gula 13\% & 7,8 \\
Karagenan 1\% Gula 15\% & 5,52 \\
Karagenan 1,5\% Gula 13\% & 7,48 \\
Karagenan 1,5\% Gula 15\% & 8,50 \\
Karagenan 2\% Gula 13\% & 7,16 \\
Karagenan 2\% Gula 15\% & 1,52 \\
\hline
\end{tabular}

Tabel 5. Rerata tingkat kesukaan panelis terhadap tekstur di mulut

\begin{tabular}{lc}
\hline \multicolumn{1}{c}{ Formula jelly drink } & Rerata tingkat kesukaan panelis \\
\hline Karagenan 1\% Gula 13\% & 6,2 \\
Karagenan 1\% Gula 15\% & 7,48 \\
Karagenan 1,5\% Gula 13\% & 7 \\
Karagenan 1,5\% Gula 15\% & 7,54 \\
Karagenan 2\% Gula 13\% & 5,88 \\
Karagenan 2\% Gula 15\% & 7 \\
\hline
\end{tabular}

\section{Tekstur di dalam mulut}

Hasil uji organoleptik terhadap tekstur di mulut jelly drink belimbing wuluh menunjukkan bahwa rerata ranking kesukaan panelis terhadap tekstur di mulut jelly drink belimbing wuluh berkisar antara 5,88-7,54. Semakin tinggi rata-rata kesukaan panelis, maka semakin tinggi pula tingkat kesukaan panelis terhadap tekstur di mulut jelly drink belimbing wuluh. Rerata nilai kesukaan panelis terhadap tekstur di mulut jelly drink belimbing wuluh disajikan pada tabel 5. Berdasarkan tabel 5, rerata nilai tingkat kesukaan panelis terhadap tekstur di mulut jelly drink belimbing wuluh pada berbagai perlakuan yang dilakukan menunjukkan jika dilihat dari persentase karigenan, terdapat hasil yang turun lalu naik lagi seiring dengan peningkatan proporsi karagenan. tingkat kesukaan panelis terhadap tekstur di mulut jelly drink belimbing wuluh pada perlakuan karagenan $1,5 \%$ dengan gula $15 \%$. Hasil analisis Uji Friedman $(\alpha=0,05)$ menunjukkan bahwa terdapat perbedaan skor dalam setiap perlakuan, yang menunjukkan bahwa ada perbedaan tekstur di mulut jelly drink belimbing wuluh pada setiap perlakuan. Perlakuan terbaik tingkat kesukaan panelis terhadap tekstur di mulut jelly drink belimbing wuluh diperoleh dari persentase karagenan $1 \%$ dengan gula $15 \%$.

Tekstur di mulut didefinisikan sebagai kesan di mulut saat makanan atau minuman berada di mulut. Tekstur di mulut yang dimaksud dalam penelitian ini adalah kemudahan untuk perasaan kesat di mulut ketika meminum jelly drink belimbing wuluh. Perubahan tekstur suatu bahan dapat mengubah rasa dan bau yang timbul karena 
dapat mempengaruhi kecepatan timbulnya rangsangan terhadap kelenjar air liur Tekstur pangan ditentukan oleh kadar air, kadar lemak, dan kandungan karbohidrat struktural seperti selulosa, pati serta protein yang terkandung dalam suatu produk (Zulkipli, 2016) Tekstur di mulut jelly drink dipengaruhi oleh tingkat keasaman, gula dan pectin (Hartati dan Djauhari, 2017). Pada penelitian ini tekstur di mulut terbaik pada persentase karagenan $1,5 \%$ dengan gula $15 \%$. Hal ini dikarenakan persentase karagenan $1,5 \%$ dengan persentase gula 15 merupakan persentase yang baik untuk menghasilkan tekstur gel yang baik. Hal ini sejalan dengan penelitian yang dilakukan oleh dimana konsentrasi karagenan 1\% menghasilkan gel yang sangat lemah dan hancur ketika dipotong dan konsentrasi karagenan 3\% menghasilkan gel yang tidak homogen dan terlalu cepat menjendal sehingga tidak bisa dicetak. Penelitian (Minarwan, 2019) juga menunjukkan gula $15 \%$ dapat menghasilkan jelly drink dengan tekstur yang diterima.

\section{Perlakuan terbaik}

Penentuan perlakuan terbaik berbagai kombinasi perlakuan jelly drink belimbing wuluh dilakukan dengan menggunakan metode indeks efektivitas. Hasil uji perlakuan terbaik didapatkan dari persentase karagenan $1,5 \%$ dengan gula $15 \%$. dengan nilai produk sebesar 2,39 dengan karakteristik sebagai berikut: rerata nilai tingkat kesukaan panelis terhadap rasa 6,23; warna 7,76; aroma 7,19; daya hisap (kemudahan untuk dihisap dengan sedotan) 8,5 ; tekstur di mulut 7,54.

\section{KESIMPULAN}

Perlakuan terbaik secara organoleptik diperoleh dari perlakuan persentase karagenan $1,5 \%$ dengan gula $15 \%$. dengan nilai produk sebesar 2,39 dengan karakteristik sebagai berikut: rerata nilai tingkat kesukaan panelis terhadap rasa 6,23; warna 7,76; aroma 7,19; daya hisap (kemudahan untuk dihisap dengan sedotan) 8,5 ; tekstur di mulut 7,54.

\section{DAFTAR PUSTAKA}

Selviana, S. (2016). Pengaruh konsentrasi karagenan dan gula pasir terhadap karakteristik minuman jelly black mulberry (morus nigra l.). [Skripsi]. Universitas Pasundan. Bandung

Agustin, F., \& Putri, W. D. R. (2013). Pembuatan jelly drink Averrhoa bilimbi l.(kajian proporsi belimbing wuluh: air dan konsentrasi karagenan). Jurnal Pangan Dan Agroindustri, 2(3), $1-9$.

Aini, M. A. Q., Rahmi, A., \& Sutoyo, S. (2019). Kajian kombinasi konsentrasi sari buah belimbing manis dan karagenan pada pembuatan jelly drink belimbing manis (averrhoa carambola l). Jurnal Teknologi Pertanian Andalas, 23(2), 158-164.

Andayani, R., Chismirina, S., \& Kumalasari, I. (2014). Pengaruh ekstrak buah belimbing wuluh (averrhoa bilimbi) terhadap interaksi streptococcus sanguinis dan streptococcus mutans secara in vitro. Cakradonya Dental Journal, 6(2), 727-736.

Eren, W. (2015). Karakterisasi komponen aroma aktif pada belimbing wuluh (averrhoa bilimbi l.) dan produk fermentasinya. [Skripsi]. Institut Pertanian Bogor. Bogor

Gani, Y.F., Indarto, T., Suseno, P., \& Surjoseputro, S. (2014). Perbedaan konsentrasi karagenan terhadap sifat fisikokimia dan organoleptik jelly drink rosela-sirsak . Journal of Food Technology And Nutrition, 13(2), 8793.

Insan, R. R., Faridah, A., Yulastri, A., \& Holinesti, R. (2019). Using belimbing wuluh (averhoa blimbi l.) as a functional food processing product. Jurnal Pendidikan Tata Boga Dan Teknologi, 1(1), 47-55.

Kusumayanti, H., Hanindito, S. B., \& Mahendrajaya, R. T. (2016). Pangan fungsional dari tanaman lokal indonesia. METANA, 12(1), 26-30. https://doi.org/10.14710/Metana.V12i1 
.17512

Marini, SM., Desniar, \& Santoso, J. (2016). Karakteristisasi minuman jelly probiotik dengan penambahan lactobacillus plantarum (sk5) asal bekasam selama penyimpanan. JPHPI, 19(3). 288-298. https://doi.org/10.17844/Jphpi.2016.19 .3 .288

Matondang, H. F., Kusumastuti, A. C., \& Nissa, C. (2017). Pengaruh pemberian sari belimbing wuluh (averrhoa bilimbi. l) terhadap adar kolesterol total wanita dewasa. Universitas Diponegoro. Semarang.

Merta, C. R. (2017). Pengaruh kadar gula terhadap kualitas permen jeli belimbing wuluh. [Skripsi]. Universitas Negeri Padang. Padang

Minarwan, M. F. (2019). Pengaruh konsentrasi sukrosa dan konsentrasi karagenan terhadap mutu jelly drink kulit buah kopi varietas arabica (coffea arabica). [Skripsi]. Universitas Pasundan. Bandung.

Nirwana, N., Candra, K. P., Emmawati, A., \& Prabowo, S. (2019). Karakteristik fisik dan sensoris rosella jelly drink dengan penambahan sarang burung walet sebagai inovasi pangan fungsional baru. Seminar Nasional Pertanian 2019. 220-228.

Tarwendah, I.P. (2017). Studi komparasi atribut sensori dan kesadaran merek produk pangan. Jurnal Pangan Dan Agroindustri, 5(2), 66-73.

Sugiarto, A. W. (2011). Pengaruh konsentrasi karagenan dan gula pasir terhadap sifat fisikokimia dan organoleptik jelly drink alang-alang (imperata cylindrica (l.) p. beauv.) [Skripsi]. Universitas Katholik Widya Mandala. Surabaya

Sugiarto, A. W. (2011). Pengaruh konsentrasi karagenan dan gula pasir terhadap sifat fisikokimia dan organoleptik jelly drink alang-alang (imperata cylindrica (l.) p. beauv.) [Phd Thesis]. Widya Mandala Catholic University Surabaya.
Susanto, D. A., Setyoko, A. T., Herjanto, S., \& Prasetiyo, A. E. (2019b). Pengembangan standar nasional indonesia (sni) pangan fungsional untuk mengurangi resiko obesitas. Jurnal Standardisasi, 21(1), 31-44. Https://doi.Org/10.31153/Js.V21i1.734

Triswandari, N. (2006). Pembuatan minuman belimbing wuluh ((averrhoa bilimbi) - jahe (zingiber officinale) dan pengujian stabilitasnya selama penyimpanan. [Skripsi]. Institut Pertanian Bogor. Bogor

Ulfa, N., Yusasrini, N. L. A., \& Ina, P. T. (2019). Pengaruh penambahan ekstrak kulit buah manggis (garcinia mangostana l.) terhadap karakteristik jelly drink. Jurnal Ilmu Dan Teknologi Pangan (ITEPA), 8(3), 285-292. Https://doi.org/10.24843/Itepa.2019.V 08.I03.P07.

Vania, J., Utomo, A. R., \& Trisnawati, C. Y. (2017). Pengaruh perbedaan konsentrasi karagenan terhadap karakteristik fisikokimia dan organoleptik jelly drink pepaya. Jurnal Teknologi Pangan Dan Gizi, 16(1), 813.

Wijanarti, S., Putra, A. B. N., Nishi, K., Harmayani, E., \& Sugahara, T. (2016). Immunostimulatory activity of snake fruit peel extract on murine macrophage-like j774. 1 cells. Cytotechnology, 68(5), 1737-1745.

ZA, N.M., Sufiat, S., \& Kamal, R. (2019). Daya terima konsumen terhadap citarasa es krim buah kawista (limonia acidissima). Media Pendidikan Gizi Dan Kuliner, 8(2), 20-27.

Zulkipli, F. M. P. (2016). Penambahan konsentrasi bahan penstabil dan gula terhadap karakteristik fruit leather murbei (morus nigra). [Skripsi]. Universitas Psundan. Bandung 